\title{
The Public Stock Buyback Tender Offer in France
}

\author{
Wided. Khiari \\ Department of Finance, \\ University of Tunisia \\ Yosra Mellouli \\ Department of Finance \\ University of Tunisia
}

\begin{abstract}
This article focuses on the public stock buyback tender offers carried out in France between 1996 and 2005. First, we will study the impact of The Public Stock Buyback Tender Offers' announcements on stock prices. The results of the event studies show that these announcements are welcomed by a very favorable price reaction. Secondly, we try to explain the premium in the repurchase mode. The results of the linear regressions show that a low level of liquidity and the securities' performance, during the period preceding the public stock buyback tender offer, seems to push companies to pay large premiums. It also appears from these regressions that smaller companies, accepting the over demand and for a significant percentage from the capital; are also encouraged to offer high premiums.
\end{abstract}

Keywords: Public Stock, Buyback Tender Offer, the Dutch auction, Toehold purchase, Repurchase on the market, the Repurchase of own Shares Program, Premium, Signaling, Undervaluation.

\section{INTRODUCTION}

The repurchase of own shares is a technique that enables listed companies to redeem a part of their securities in the stock exchange. In France, two methods of redemption are possible: Toehold purchase (or repurchase on the market) and The Public Stock Buyback Tender Offer at a fixed price (hereinafter, The Public Stock Buyback Tender Offer).

Under the first method, the listed company is presenting itself on the market as an ordinary buyer in order to repurchase its own shares. This redemption is made at the market price and shall not exceed $10 \%$ of the company's capital. However, The Public Stock Buyback Tender Offer allows listed companies to buy back an unlimited part of their capital at a price fixed in advance, which is generally higher than the market price at the announcement date of the operation.

The Public Stock Buyback Tender Offer is a very little used practice compared to repurchases on the market. In the US market, Barclay and Smith (1988) show that in 1986, 12.4\% of companies, listed on the NYSE, use repurchase on the market, and only $2.79 \%$ chose The Public Stock Buyback Tender Offer. Also, according Grullon and Michaely (2004), the repurchases on the market represent $90 \%$ of the repurchases made over the period 1984-2004.

In France, 47 Public Stock Buyback Tender Offers were made between 1996 and 2005. This number varies depending on the year. The maximum was only reached in 2003 with "10" Public Stock Buyback Tender Offers in the year, for an amount of 0.284 billion€. As for repurchase on the market, they have experienced unprecedented growth after the evolution of 
their legal status in July 1982. Thus, between July 1998 and December 2003, the average annual amount allocated to the implementation of buyback programs exceeds 13 billion $€$ (see Figure 1 and 2) ${ }^{1}$. Thus, the latter mechanism is the most important one.

This is explained by the fact that the Public Stock Buyback Tender offers are much less flexible and more expensive than the repurchase on the market. Indeed, such decision via the latter method enables companies to withdraw and / or distribute repurchases over a longer period than as permitted by a repurchase by a Public Stock Buyback Tender offer. In addition, the offers are generally made at a price higher than the current market price, that is to say with a premium. But for the repurchase on the market, the premium is very low and even nonexistent.

Although the Public Stock Buyback Tender Offers have several limitations, they are sometimes beneficial for businesses. First, these operations can be essential when the company wants to buy a high percentage of its capital, exceeding the limit of $10 \%$ allowed by the repurchases on the market.

Next, we note that companies are making repurchases primarily to indicate to the market the undervaluation of their securities. This objective can be achieved by tenders and by repurchases on the market. However, the premium of the first repurchase method makes the undervaluation signal more expensive and therefore more credible than the one conveyed by the repurchases on the market method. The informational power of offers is much more important; and their positive impact on the securities' prices will normally be more accentuated.

Besides these two main reasons, the Public Stock Buyback Tender Offer can provide a company the first step towards the delisting, an anti-takeover defense, or a way to reduce existing agency conflicts within the organization

This study has two aims. First, we will study the impact of the Public Stock Buyback Tender Offer on stock prices. The results of event studies highlight the positive response of the French market with these operations' announcements: $+14 \%$ over the period $(0.1)$. This highly positive response demonstrates the credibility of the undervaluation signal sent from tenders, where the premium paid plays a vital role.

It seems interesting to consider, in a second time, the determinants of the premium. The empirical results show that the size of the company, its liquidity and the performance of securities during the period preceding the announcement, have a negative influence on the amount of the premium. However, the acceptance of the over demand by the companies and the importance of the size of the operation have positive effects.

In the first section, we will focus on the reasons why businesses carry out Public Stock Buyback Tender Offers. In the second section, we will present the study sample, the data sources and the methodology. The object of the third section will be the impact of the Public Stock Buyback Tender Offers' announcements on the stock prices. The fourth section will describe the determinants of the premium in an offer.

\footnotetext{
${ }^{1}$ Source: www.amf-france.org.
} 


\section{The Motivations of the Public Stock Buyback Tender Offers}

In France, two repurchase methods are possible: The Repurchase on the Market in which the listed company presents itself on the market as an ordinary buyer in order to repurchase its own shares and the Public Stock Buyback Tender Offer.

In addition to these two methods of redemption, in the United States, companies have at their disposal two mechanisms: the Dutch auction (Dutch-auction self-tender offer) and the share repurchase coupons that the company delivers to shareholders to buy their shares at a certain price.

Given the existence of all these possibilities, the question arises: why does a company use more the method of share repurchase via a tender offer over another share repurchase method?

The companies use Public Stock Buyback Tender Offers, in particular to bypass one of the main obstacles for the repurchase on the market, namely the limits of the number of shares to be repurchased. The repurchase on the market is framed in most countries by strict rules, because of the risk of price manipulation it implies. In France, it cannot exceed 10\% of the company's capital. That's why when a company wants to buy a large number of actions- over the authorized limit - it must use the Public Stock Buyback Tender Offer.

This section also will review other reasons justifying the use of a company of public offering to repurchase shares. First, we are interested in the standard explanations of the Public Stock Buyback Tender Offer as the delisting of the company's securities, the expropriation of creditors, the anti-takeover defense and the reduction of agency conflicts. Then we will focus on the signaling of the undervaluation of the company, which seems to dominate the literature

\section{The Delisting of the Company's Securities}

Companies that engage in a Public Stock Buyback Tender Offer often announce the desire to withdraw their shares of the market. The presence of abundant liquidity and the absence of growth opportunities encourage managers to fund insufficiently profitable projects; causing conflicts between managers and shareholders (Jensen, 1986).

In this case, the best solution for the company is to repurchase its own shares to remunerate its shareholders and thus reduce agency conflicts. The repurchase on the market allows to buy only a limited number of shares. The company that wishes to see its security delisted and get back to being a private company, must necessarily resort to the Public Stock Buyback Tender Offer.

The company may also propose to repurchase a number of shares corresponding to the required proportion that allows it to be delisted from the stock exchange. Once these shares repurchased, it may then proceed with a public repurchase offer with, for example, a squeezeout, which will result in the delisting of the company's securities

\section{Expropriation of the Creditors}

The repurchase of shares by cash or by debt reduces the asset value of the company and therefore the collateral value of the creditors. Assuming that this was not anticipated when the company's notes were issued, there is then a transfer of wealth from creditors to shareholders. It should be noted that this transfer of wealth can be generated by the two methods of repurchase. However, it is more pronounced in the case of a Public Stock Buyback Tender Offer. Thus, due to its unlimited scope, the latter repurchase method can significantly amputate the equity value of the company. For cons, the repurchase on the market does not allow 
companies to redeem more than $10 \%$ of their capital and cannot therefore lead to a major readjustment of the financial structure of the company.

Empirically, the impact of the Public Stock Buyback Tender Offers on the wealth of creditors was initially studied by Dann (1981). This study shows conflicting results of the expropriation hypothesis of creditors by highlighting the positive impact of 143 Public Stock Buyback Tender Offers on convertible bonds. More recently, the study of Maxwell and Stephens (2003) confirms this hypothesis, not with a Public Stock Buyback Tender Offer sample, but with 945 repurchase programs on the market.

\section{The Anti- Public Tender Defense}

The Public Stock Buyback Tender Offer can be used as an anti-public tender weapon. Thus, paying an acquisition premium higher than to the one it is originally planned to offer, the company has the opportunity to acquire the securities of shareholders who have not responded to the Public Stock Buyback Tender Offer. The acquisition cost of the company to the potential buyer becomes necessarily higher; which makes the company less attractive and therefore less likely to be the subject of a public tender (Comment and Jarrell, 1991 and Fried, 2005). In other words, a Public Stock Buyback Tender Offer with high premium increases the cost of a public tender and therefore weaken its probability of occurrence.

A second explanation attempting to highlight the public tender defense character is based on the agency theory. If the managing shareholders and the majority shareholders do not offer their shares in the context of a Public Stock Buyback Tender Offer or on the market, this necessarily leads to an increase of their participation in the company's capital. Insofar as the acquisition premium of a takeover is even higher than the proportion of the managing shareholders is important, the Public Stock Buyback Tender Offer reduces the probability of acquisition (Bagwell, 1988 and Stulz, 1988). This mechanism then benefits the shareholders, forcing the potential buyer of the company to pay a higher premium for each target shares.

It should be noted that as part of an anti- public tender strategy, the Public Stock Buyback Tender Offer generates a concentration of the voting rights in the hands of the managers and can therefore lead to the deep-rootedness of these mangers. However, in some cases, the deeprootedness of managers can hamper the value of the company and thus causes agency conflicts within the organization. The Public Stock Buyback Tender Offer can also help to resolve these conflicts by clearing the excess cash of the company.

\section{Agency Conflicts Reduction}

The desire to reduce agency conflicts between shareholders and managers can justify the use of the Public Stock Buyback Tender Offer by the companies. The presence of an excess cash and the lack of growth opportunities increase the mangers' tendency to fund insufficiently profitable projects or to use available funds for personal purposes. This can result in the destruction of the company value, which causes conflicts of agency between shareholders and managers (Jensen, 1986). In order to alleviate these conflicts, managers should provide the shareholders with the funds available.

In this case, managers have an alternative to meet the demands of their shareholders in terms of remuneration; they can use the repurchase of shares - Public Stock Buyback Tender Offer or repurchase on the market- or the dividend. However, the first mode of payment is generally 
preferred over the second. Unlike the regular dividend ${ }^{2}$, repurchases have the advantage of being one-off operations that do not commit the company to maintain the payment for the years to come.

The Public Stock Buyback Tender Offer may also help the company resolve the agency conflicts resulting in an increase in leverage. The Public Stock Buyback Tender Offer through debt financing may result in discipline managers. Indeed, the financial pressure caused by the increase in leverage encourages managers to maximize the company's value to cope with debt maturities. The rapprochement of the shareholders' interests with those of the managers, reduces agency conflicts.

The reduction of agency conflicts following the Public Stock Buyback Tender Offer can be one of the explanations for the positive price reaction to the announcement of such an operation (Howe et al., 1992; Perfect and al., 1995; Nohel and Tarhan, 1998).

According to these authors, investors give a favorable welcome to Public Stock Buyback Tender Offers' announcements, because they allow companies to efficiently use their available cash and by the way reduce conflicts between managers and shareholders.

It is important to note that the reduction of conflicts between shareholders and managers can also be obtained through other mechanisms which are less expensive, such as the repurchase on the market. Thus, this reason represents a no satisfactory explanation on the use of the Public Stock Buyback Tender Offers by companies.

\section{Public Stock Buyback Tender Offers and the signal theory}

The Public Stock Buyback Tender Offers' announcement usually brings good news for investors, because it reports a potential undervaluation of the company's shares. In the presence of asymmetric information, managers have generally a better understanding of the prospects of the company; announce a Public Stock Buyback Tender Offer when they feel their company is undervalued. This operation in which managers decide to distribute cash instead of investing in unprofitable projects and pay a premium according to the current share price, reports the good management of these latter. It also reflects a favorable anticipation of future profits. In this case, considering the semi-strong form of efficiency markets ${ }^{3}$, the Public Stock Buyback Tender Offer's announcement must be immediately accompanied by a positive market reaction.

Empirically, to our knowledge, all the studies on this subject confirm this hypothesis and show significantly positive abnormal returns associated with thePublic Stock Buyback Tender Offer's announcement (Vermaelen, 1984; Masulis, 1980; Lakonishok and Vermaelen, 1990; Comment and Jarrell 1991 Howe et al. 1992 D'Mello and Shroff, 2000, and Anderson and Edward, 2004).

2 According to DeAngelo, DeAngelo and Skinner (2000), one-off dividend payments are still possible, but they became in the 1990s increasingly rare.

3 The efficient financial market hypothesis in its semi-strong form implies that the market incorporates every information when the hypothesis is released. Transaction costs related to the issuance 
Table 1: Reaction of the stock market prices to the Public Stock Buyback Tender Offer (PSBTO) in France

\begin{tabular}{|l|l|l|l|l|}
\hline The study & Market & $\begin{array}{l}\text { PSBTO } \\
\text { number }\end{array}$ & Period & AAR or ACAR \\
\hline Vermaelen (1984) & USA & 131 & $1962-1977$ & $+15 \%$ \\
\hline Masulis (1980) & USA & 199 & $1963-1978$ & $+17 \%$ \\
\hline $\begin{array}{l}\text { Lakonishok et Vermaelen } \\
\text { 1990) }\end{array}$ & USA & 258 & $1962-1986$ & $14,29 \%$ on $[-5,+10]$ \\
\hline $\begin{array}{l}\text { Comment et Jarrell (1991) } \\
\text { (1991) }\end{array}$ & USA & 68 & $1984-1989$ & $11 \%$ on $[-1,+1]$ \\
\hline Hertzel (1991) & USA & 122 & $1969-1978$ & $17,68 \%$ on $[-1,0]$ \\
\hline Hertzel and Jain (1991) & USA & 127 & $1970-1984$ & $10,1 \%$ on $[-1,1]$ \\
\hline Howe, He et Kao (1992) & USA & 55 & $1979-1989$ & $7,47 \%$ on $[-1,0]$ \\
\hline $\begin{array}{l}\text { Barnes, Burnie et Gunay } \\
\text { (1997) }\end{array}$ & $\begin{array}{l}\text { Canada } \\
\text { (Toronto }\end{array}$ & $\begin{array}{l}275 \\
\text { (firms) }\end{array}$ & $1987-1995$ & $31,34 \%$ on $[-1,+1]$ \\
\hline Choi and Chen (1997) & USA & 53 & $1968-1984$ & $13,07 \%$ on $[-1,0]$ \\
\hline Lie and McConnell (1998) & USA & 130 & $1981-1994$ & $7,9 \%$ on $[-1,+1]$ \\
\hline Nohel and Tarhan* (1998) & USA & 242 & $1978-1991$ & $7,60 \%$ on $[-1,+1]$ \\
\hline D'Mello and Shroff (2000) & USA & 166 & $1970-1989$ & $14,10 \%$ on $[-1,+1]$ \\
\hline Lie (2002) & USA & 286 & $1980-1987$ & $9,4 \%$ on $[-1,+1]$ \\
\hline Anderson et Edward (2004) & USA & 399 & $1970-1999$ & $13,31 \%$ on $[-1,+1]$ \\
\hline
\end{tabular}

In the US market, the abnormal returns were about 16 to $17 \%$ in 1970 and increased in 1980 to around 8\%. Recently, on a sample of 399 Public Stock Buyback Tender Offers between 1970 and 1990, Edward and Anderson (2004) show a positive price reaction to announcements of offers: $+13.31 \%$ over the period $(-1.1)$. Although less pronounced, this positive response is also confirmed in the Canadian market by Barnes, Burnie and Gunay (1997): $+1.34 \%$ over the period (-1.1). The direct test of undervaluation of companies conducting Public Stock Buyback Tender Offers further strengthens the signaling hypothesis. By comparing the economic value of the companies with their market value, D'Mello and Shroff (2000) found that 74\% of companies that carry out Public Stock Buyback Tender Offers in their sample are undervalued.

The studies also agree on the long-term nature of the price increase following the Public Stock Buyback Tender Offer. Thus, Vermaelen (1984) find that the offers are followed by a permanent rise in the price of the security. Lakonishok and Vermaelen (1990) add that the companies conductingPublic Stock Buyback Tender Offers have significantly positive abnormal returns during the two years following the offer.

It should be noted that the announcement of the repurchase methods also cause a rise in prices. However, the authors still show that the announcement of aPublic Stock Buyback Tender Offerhas the strongest favorable impact. Indeed, in the framework of a Public Stock Buyback Tender Offer, the company pays a higher premium than in other repurchase methods. The Public Stock Buyback Tender Offers are then the more expensive repurchase operation. To this end, the undervaluation signal of the securities sent by the offers' announcements is more credible than that one conveyed by the Dutch auction or the repurchase on the market. 
Regarding the two methods of public offering, Comment and Jarrell (1991) found that in the case of Public Stock Buyback Tender Offers, the abnormal returns are of the order of 8.3\%, while in the case of Dutch auctions, they are of the order of $7.5 \%$. According to them, the premium in the case of the first method is set by the managers themselves; it is higher than the one generally provided in the case of the second method. This implies a much more credible and therefore stronger signal for the Public Stock Buyback Tender Offers. Similarly, the fact that the repurchases on the market are made according to the prevailing prices in the market at the time of the repurchase (that is to say without premium) makes their impact on stock prices much lower than that one generated by the Public Stock Buyback Tender Offers' announcements. Empirically, the difference in price reaction between these two methods of repurchase is clearly remarkable. Thus, in the US market, the reaction of shares following the Public Stock Buyback Tender Offers' announcements vary, depending on the studies, between $17 \%$ and $7.9 \%$ (see Table 1). However, on the same market, this reaction is around $3 \%$ for the announcements of the repurchase on the market programs (Comment and Jarrell, 1991; Ikenberry and al., 1995; Stephens and Weisbach, 1998; Guay and Harford , 2000 and Grullon and Michaely, 2000).

The market reaction associated with the repurchase announcements depends not only on the repurchase mechanism used. It is also affected by several factors related to the issuer, to the security and to the operation characteristics. In fact, in most studies, the company size, liquidity, the performance of the securities before the announcement and the participation of managers in the operation, negatively influence the price reaction to the Public Stock Buyback Tender Offers' announcements. By cons, the size of the operation records a positive effect 7 .

In summary, the various studies converge on the favorable market reaction following the announcement of a Public Stock Buyback Tender Offer. They add that this reaction is stronger than that seen following the announcements of other repurchase methods.

\section{The reaction of the French market to the Public Stock Buyback Tender Offers' announcements}

In this section, we, first, present the study sample. Then, before presenting our results, we will explain the methodology used.

\section{Sample Presentation}

In this study, the sample includes the Public Stock Buyback Tender Offers carried out in France between 1996 and 2005. Initially, it is based on 47 operations from 41 companies, which presents all the offers made on the French market during this period. The number of the Public Stock Buyback Tender Offers varies by year. The maximum is reached in 2003 with "10" Public Stock Buyback Tender Offers a year.

We have removed 3 Public Stock Buyback Tender Offers, conducted in 1996, for which the market data are not available in the database "DataStream". We also removed two operations that we were unable to determine their announcement dates. Thus, the final sample includes 42 Public Stock Buyback Tender Offers between 1996 and 2005.

Table 2.1 : PSBTO annual distribution

\begin{tabular}{|l|lllllllllll|l|}
\hline Year & \multicolumn{7}{|c|}{$1996-1997-1998-1999-2000-2001-2002-2003-2004-2005$} & Total \\
\hline Initial sample & 5 & 4 & 6 & 2 & 3 & 5 & 2 & 10 & 5 & 5 & 47 \\
\hline Final sample & 2 & 4 & 6 & 1 & 3 & 5 & 1 & 10 & 5 & 4 & 42 \\
\hline
\end{tabular}


By distinguishing 3 groups based on their listing market, we note that in most cases the Public Stock Buyback Tender Offers of the companies listed on the "Second Marché" is (45.2\%). The offers made by the leading market companies come second with 40.5\%. However, the Public Stock Buyback Tender Offers of the companies listed on the "Nouveau Marché" represent only $14.3 \%$ of the entire sample.

Table 2.2 : PSBTO distribution according to the firm's listing market

\begin{tabular}{|l|l|}
\hline$\%$ of PSBTO concerning firms listed on the First Market & $40,5 \%$ \\
\hline$\%$ of PSBTO concerning firms listed on the Second Market & $45,2 \%$ \\
\hline$\%$ of PSBTO concerning firms listed on the New Market & $14,3 \%$ \\
\hline
\end{tabular}

Any company wishing to perform a Public Stock Buyback Tender Offer must provide an information note to the Financial Markets Authority (AMF). This note will present the offer and detail the reasons for the operation, the company's intentions, the terms (number of shares repurchased, at what price), the intentions of the company's major Shareholders, the timing of operation (start and end of the Public Stock Buyback Tender Offer, the results publication dates) and the financing of the operation ${ }^{8}$.

In the notes, companies generally mention several objectives (the priority order is not specified). We kept the five essential motivations. The main reason given by companies is the one that consists in enabling shareholders to realize their investment by presenting their securities with the offer. Often this reason is related to the insignificant liquidity conditions of the action: the company hopes to improve this liquidity and the monitoring of the security by analysts and through the Public Stock Buyback Tender Offer. This motivation is stated 24 times by companies. The next reason is the existence of significant cash. In total 18 Public Stock Buyback Tender Offers announce it. The third reason is the optimization of the financial structure and return on equity (stated 9 times by companies). Stock prices regularization can also justify the companies' use of Public Stock Buyback Tender Offers (stated 8 times by companies). Finally, 7 Public Stock Buyback Tender Offers that have the lack of profitable projects as a motive.

Table 2.3 : PSBTO motivations

\begin{tabular}{|l|l|}
\hline PSBTO Motivations & Frequency \\
\hline Allow shareholders who wish to sell their shares & 24 times \\
\hline Existence of a large cash & 18 times \\
\hline Lack of profitable projects & 7 times \\
\hline Prices regularization & 8 times \\
\hline Optimizing the financial structure and equity profitability & 9 times \\
\hline
\end{tabular}

Regarding financing methods, we find that in most cases the Public Stock Buyback Tender Offer is funded exclusively by cash available in the company (71.4\%). For cons, the exclusive debt financing is mentioned in less than 3\% (one Public Stock Buyback Tender Offer) of the offers. For other Public Stock Buyback Tender Offers, $21.4 \%$ announce funding by cash and debt, and $4.7 \%$ did not specify the financing method adopted.

Table 2.4 : Financing methods

\begin{tabular}{|l|l|}
\hline Financing Methods & $\%$ of PSBTO \\
\hline Fully financed by cash & $71,4 \%$ \\
\hline Exclusive debt financing & $2,4 \%$ \\
\hline Financed by cash and debt & $21,4 \%$ \\
\hline
\end{tabular}


The information note also clarifies the company's decision regarding the acceptance or not of the repurchase of the over demand. Thus, when the number of shares that the shareholders propose to repurchase exceeds the number that the company originally intended to repurchase, two cases are possible: either a pro rata reduction of the demand where all the offers are reduced to the same number of the securities repurchased as the securities offered; or repurchase of all or part of the over demand.

Companies that take that decision are fewer in number than the others; they represent about $36 \%$ of the sample.

In addition, the major shareholder can reveal, in the note, if he wishes or not to put his shares under a Public Stock Buyback Tender Offer. In our sample, we found that in almost 43\% of cases, the shareholder declares to participate in a Public Stock Buyback Tender Offer.

Finally, once its shares repurchased, the company may make a public delisting offer, with for example, a mandatory delisting, which will result in the delisting of the company's securities. In our case, only $26 \%$ of the Public Stock Buyback Tender Offers made this decision.

Table 2.5 : PSBTO other characteristics

\begin{tabular}{|l|l|}
\hline Decision & Favorable decision \\
\hline Participation of the majority shareholder in PSBTO & $42,8 \%$ \\
\hline The company's acceptance of the repurchase request & $35,71 \%$ \\
\hline withdrawal of offers following the PSBTO & $26,1 \%$ \\
\hline
\end{tabular}

The information about the characteristics of the offer comes from the Public Stock Buyback Tender Offer's information notes issued by the AMF. Daily market data were collected from the database "DataStream". Finally, the announcement dates, often corresponding to the filing date of the offer document with the AMF, dates of suspension and restarting of the listing during the offer period are from the base« FinInfo».

\section{METHODOLOGY}

To measure the price reaction to Public Stock Buyback Tender Offers' announcements, the event study's methodology is used. This method measures the impact of a particular signal on the stock prices reaction. It is based on the hypothesis of the semi-strong efficiency of the capital markets. In other words, it assumes that all published information is immediately incorporated into the market securities price.

The impact of an event on the stock prices during the period (named event period) is measured by an abnormal profitability. This latter is the difference between the observed actual profitability during a period (called estimation period) and a standard. The standard corresponds to the expected profitability of the security in the absence of the estimated event, and it is called normal profitability. Generally, the standard is estimated by one of the three following forecasts models:

-The Model of returns adjusted by the average

-The Model of returns adjusted by the market index

-The Models of returns adjusted by the market movements and the risk: the market model.

This model is the most common and the one applied in our study. 
Before explaining the calculation of abnormal returns, we define the time scale of the event study, such as the announcement date, the period of the event and the estimation period.

The study of the impact of an information announcement on the stock prices normally mean centration of the event study on the announcement date of the operation. However, in the case of a Public Stock Buyback Tender Offer, the listing is usually suspended at the time of announcement (usually the day before or the same day) and resume again a few days later. Due to the suspension of the rating, the event window is centered around the resumption date of the listing (which is the date 0) and not the date of the Public Stock Buyback Tender Offer's announcement.

The length of the estimation period and that of the event window are left to the researcher appreciation. In our study, the estimation period is 90 days before the event period. The event window has a duration of 21 days spread over a time interval $[-10,+10]$ specific to each security. We note that outside this range, the flow of information about the security is supposed to be normal.

By applying the Market Model, we first determine the abnormal returns of the security i at time $\mathrm{t}$ as follows:

$$
R A_{i t}=R_{i t}-\left(\alpha_{t}+\beta_{t} R_{m t}\right) \quad \forall t \in[-T, T]
$$

With: $\mathrm{R}_{\mathrm{it}}$ is the observed return of the security $i$ at time $t$.

$\left(\alpha_{t}+\beta_{t} R_{m t}\right)$ is the normal return of the security i at time $t$

$\alpha_{t}$ et $\beta_{t}$ are the parameters of the market model estimated during the chosen estimation period. This period, in our study, is from -90 to -10 days from the date of "0".

$[-\mathrm{T}, \mathrm{T}]$ is the event period, in the course of our study, a period of 21 days spread over a time interval $[-10,+10]$ specific to each security.

Then, to measure the average impact of the event on the stock market prices of the securities of the sample at time $t$, we calculate the average abnormal return as follows:

With:

$$
A A R t=1 / n \sum A R i t \forall t \in[-T, T]
$$

$\mathrm{n}$ is the number of security of the total sample. In our case, $\mathrm{n}$ is the 42 Public Stock Buyback Tender Offers studied.

In addition, the average cumulative abnormal return is calculated to test the influence of the event between two different times. Its definition is as follows:

$\mathrm{t} 2$

$$
\operatorname{ACAR}_{(\mathrm{t} 1 ; \mathrm{t} 2)}=\sum \mathrm{AAR}_{\mathrm{t}} \mathrm{t}
$$

Finally, the Student test is used to test the statistical significance of the AAR and ACAR.

\section{RESULTS OF THE EVENT STUDY}

The results of the study event show in the first place that the market reaction following the Public Stock Buyback Tender Offer's announcements varies between $-0.46 \%$ and $+0.86 \%$ during the 10 days preceding the announcement. This reaction does not record any clear trend. 
This suggests that the operation of the offer was not anticipated by the market. At the Public Stock Buyback Tender Offer announcement date, the price reaction shows a statistically significant increase (at $1 \%$ level) of $13.38 \%$. Positive feedback also persists after the announcement: $+13.55 \%$ during the period $(0,60)$.

Tableau 3: Average and cumulative abnormal returns (AAR and ACAR) associated to announcement of PSBTO

\begin{tabular}{|l|l|l|l|l|l|}
\hline \multicolumn{1}{r}{ day } & AAR $(\%)$ & \multicolumn{1}{c|}{ Student T } & window & ACAR(\%) & Student T \\
\hline $\mathrm{J}-10$ & 0,861 & $1,950^{*}$ & {$[0,1]$} & 14,049 & $5,796^{* * *}$ \\
$\mathrm{~J}-9$ & 0,500 & 0,513 & {$[0,10]$} & 16,094 & $5,680^{* * *}$ \\
\hline $\mathrm{J}-8$ & 0,304 & 1,342 & {$[0,20]$} & 15,765 & $4,618^{* * *}$ \\
$\mathrm{~J}-7$ & $-0,464$ & $-1,117$ & {$[0,30]$} & 12,364 & $3,216^{* * *}$ \\
$\mathrm{~J}-6$ & 0,084 & 0,237 & {$[0,40]$} & 12,495 & $2,772^{* * *}$ \\
$\mathrm{~J}-5$ & $-0,043$ & $-0,124$ & {$[0,50]$} & 11,622 & $2,107^{* *}$ \\
$\mathrm{~J}-4$ & $-0,111$ & $-0,273$ & {$[0,60]$} & 13,552 & $1,957^{*}$ \\
\hline
\end{tabular}

\begin{tabular}{lll|}
\hline $\mathrm{J}-3$ & $-0,463$ & $-0,681$ \\
\hline $\mathrm{J}-2$ & 0,178 & 0,539 \\
\hline $\mathrm{J}-1$ & $-0,207$ & $-0,631$ \\
\hline $\mathrm{J}=0$ & 13,383 & $5,352^{* * *}$ \\
\hline $\mathrm{J}+1$ & 0,666 & 1,175 \\
\hline $\mathrm{J}+2$ & 1,404 & 0,787 \\
\hline $\mathrm{J}+3$ & 0,444 & 1,018 \\
$\mathrm{~J}+4$ & $-0,303$ & $-1,240$ \\
$\mathrm{~J}+5$ & 0,655 & 0,669 \\
\hline $\mathrm{J}+6$ & 0,162 & 0,415 \\
\hline $\mathrm{J}+7$ & $-0,366$ & $-1,177$ \\
\hline $\mathrm{J}+8$ & 0,304 & 1,335 \\
\hline $\mathrm{J}+9$ & 0,168 & 1,089 \\
\hline $\mathrm{J}+10$ & $-0,425$ & $-1,187$ \\
\hline
\end{tabular}

Figure 1: AAR and ACAR $[-10,10]$ associated to PSBTO announcement

*** significance at $1 \%$ threshold

** significance at $5 \%$ threshold

* significance at $10 \%$ threshold

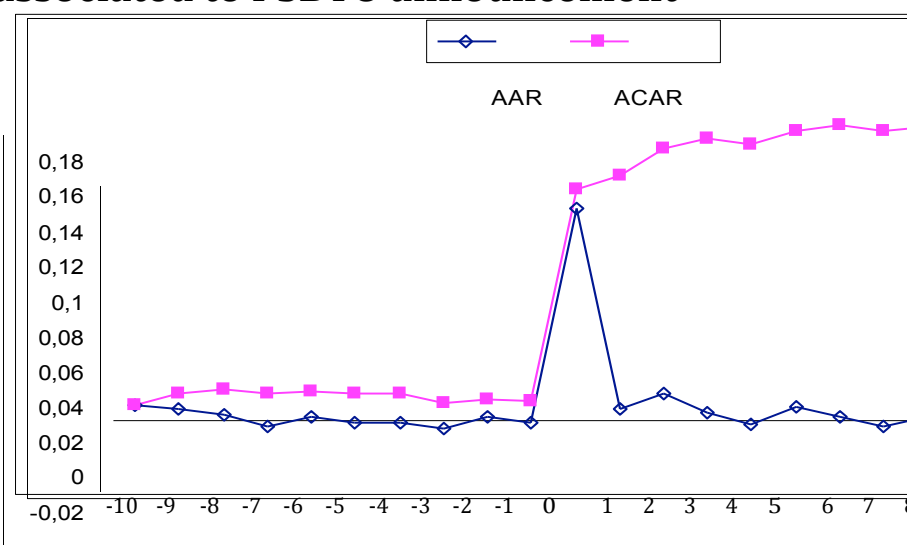

Thus, the results show the favorable French market reaction to the Public Stock Buyback Tender Offers' announcements. They are comparable to those found in the US market (see Table1). For example, the recent increase of prices after the Public Stock Buyback Tender Offers announcements, that was recorded by Anderson and Edward (2004) of 13,31\% over the period $(-1,+1)$.

The results highlight the importance of the favorable market reaction to the Public Stock Buyback Tender Offers' announcements compared to the one observed following the announcements of the repurchase programs. In the period (0.1), we find a positive price response in the order of $+14 \%$. In contrast, during the same period, with the announcement of a share repurchase program on the French market, is received by a less favorable reaction: + 0.57\% (Ginglinger and L'Her 2006).

The importance of the Public Stock Buyback Tender Offer's informational role demonstrates the credibility of the signal sent by these operations, where the premium paid plays a crucial role. 


\section{Determinants of the Public Stock Buyback Tender Offer's premium}

The second section of this study examines the determinants of the premium offered in a Public Stock Buyback Tender Offer. For this, we use linear regression, traditionally used to measure the influence of a group of explanatory variables on a dependent variable. Before presenting the results, we explain these two types of variables.

\section{The Dependent Variable}

In the framework of a Public Stock Buyback Tender Offer, the premium is the surcharge paid by the company in relation to the share price on the market. It is a key way for investors as it allows them to learn about the extent of the undervaluation of the companies' securities before the offer. This can be explained by two reasons. First, a significant premium makes the Public Stock Buyback Tender Offer more expensive. To this end, the motivation of the companies carrying out Public Stock Buyback Tender Offers, and which the signaling of the securities' undervaluation, is usually the main one, seem more credible. In addition, the premium allows investors to estimate the "true" value of the security, which is usually close to the offer price.

In this context, Comment and Jarrell (1991) empirically show that the credibility of the undervaluation signal requires the non-participation of the managers in the offer and also a premium higher by at least $2 \%$ to the prevailing market price four days before the announcement of the offer. Thus, by not offering their securities despite a significant premium, the managers report, in a credible manner, that the action is worth more than the repurchase price.

Also, At an empirical level, Lakonishok and Vermaelen (1990) and D'Mello and Shroff (2000) show a strong positive correlation between the premium of the offer and the undervaluation of the companies carrying out the Public Stock Buyback Tender Offer.( de aumoins2\%)

Moreover, the premium provides the Public Stock Buyback Tender Offer with an advantage over other methods of repurchase. The premium in the case of a Public Stock Buyback Tender Offer is often greater than the one offered by the Dutch auctions. The announcements in latter repurchase method carry out a less credible undervaluation signal and therefore generate abnormal returns less favorable than the announcements of the Public Stock Buyback Tender Offer. This difference in response is more noticeable between the OPRA and the repurchase on the market that are made without premium. Comment and Jarrell (1991) validate the latter two findings. Following the results of their study, the market reaction is $11 \%$ favorable for the Public Stock Buyback Tender Offers, against 7.9\% for the announcements of Dutch auctions, which is still above the reaction associated with the announcements of the repurchases on the market (3\%).

In the briefing notes published by French companies with the AMF, premiums may be presented in several ways. In most cases, the premium is calculated as compared to the last quoted price before the Public Stock Buyback Tender Offer's announcement. It can also be calculated as compared to the average price during the month preceding the announcement or from the average price over the last three months prior to the offer.

In this study, the dependent variable chosen is the premium as compared to the last quoted price before the announcement. In our sample, which covers 42 French Public Stock Buyback Tender Offers, this premium varies between $4 \%$ and $265 \%$. The final premium is paid by the company "ICBT Group " that completed the Public Stock Buyback Tender Offer following a capital restructuration. That is why the premium paid by the company is excessively high. However, according to Planchon (2005), the presence of extreme values can lead to biased 
estimates of parameters and, following the completion of statistical tests, interpretation of results that can be very corrupt. This phenomenon may be accentuated in our case, given the small sample size (42 Public Stock Buyback Tender Offers). To this end, in order to avoid undue influence of extreme observations, we eliminated two Public Stock Buyback Tender Offers that offered particularly surprising premiums for and statistically discordant values compared to the values of other premiums paid. Empirical tests explain the determinants of the premium carried out on a sample of 40 Public Stock Buyback Tender Offers between 1996 and 2005.

\section{Hypothesis and Explanatory variables}

Two categories of explanatory variables are used. The first brings together those related to the issuing company, such as its size, the liquidity and the performance of its securities before the offer and its decision concerning the acceptance of the over demand. The second includes variables that are related to the offer, such as the fraction of the target capital and the participation of the majority shareholder in the operation.

\section{The Size of the Company}

The favorable price reaction to the Public Stock Buyback Tender Offer's announcements is usually accentuated for smaller companies. The different market reaction according to the size of the company, correspond to the motivations of the offer. Large companies use Public Stock Buyback Tender Offers to restructure their capital, while small companies use itto report the signal of undervaluation to the market. The smaller companies are less followed by financial analysts and mis-evaluated by the market, increasing the level of information asymmetry (see Merton, 1987). These companies are frequently required to reveal their undervaluation through Public Stock Buyback Tender Offers than other companies. Thus, they have an interest in paying high premiums to increase the credibility of this signal and further increase the value of their securities following the announcement of the offer. The first hypothesis can be stated as follows:

$\mathbf{H}_{1}$ :The Public Stock Buyback Tender Offer's premium is even more important when the company is small

This hypothesis was confirmed by most studies (Lakonishok and Vermaelen, 1990 Comment and Jarrell, 1991 and Anderson and Edward, 2004).

The size of the company (SIZE F) will be measured by the logarithm of the market capitalization of the company at the date of the last closing price prior to the announcement of the Public Stock Buyback Tender Offer. The expected relationship between the logarithm of the company and the premium is negative.

\section{The performance of the companies' securities before the offer}

As we have already stated, the premium of the offer is the most important signalization variable. It allows investors to learn about the credibility of the undervaluation signal sent by the Public Stock Buyback Tender Offers' announcements. To this end, the more undervalued the securities are before the offer, and therefore less efficient, the more the companies are encouraged to pay a significant premium to report to investors the extent of this undervaluation. 
Thus, we formulate the following hypothesis:

$\mathbf{H}_{2}$ :The Public Stock Buyback Tender Offer's premium is even more important than the performance of the companies' securities when the offer is low.

Dann et al. (1991) confirm this hypothesis by showing that the share price increases significantly after a Public Stock Buyback Tender Offer's announcement, when the "net" performances of the share were negative before the announcement. Comment and Jarrell (1991) and Anderson and Edward (2004) further strengthen this hypothesis by finding a negative and significant relationship between the premium paid and the undervaluation of the securities before the offer.

To calculate the performance of securities prior to the announcement, these two studies use two different measures. Anderson and Edward (2004) calculate the ratio between the price of the securities on day - 30 with respect to the offer's announcement date and the price observed on day -500 at the same date. However, Comment and Jarrell (1991) calculate the ACAR over a period preceding the announcement of the Public Stock Buyback Tender Offer. In this study, we adopt the latter measure ${ }^{13}$. Specifically, we calculate the ACAR about two months before the announcement that is to say during the period $(-60,-1)$. This variable denoted PERF is supposed to be negatively related to the premium.

\section{The Liquidity of the Company's Securities before the Offer}

The liquidity of securities may increase the information content of their value. Thus, the importance of the transaction volume decreases the information asymmetry level insofar as the more the security is traded the more the market value gets close to the real value of the company. Companies' securities with a low level of liquidity are thus characterized by a high level of information asymmetry and so they are mis-evaluated by the market. They proceed to the Public Stock Buyback Tender Offers primarily to signal the undervaluation of their securities and to increase their market value. To achieve this goal, these companies are encouraged to offer large premiums. Thus, we can formulate the following hypothesis:

$\mathbf{H}_{3}$ : The premium of the Public Stock Buyback Tender Offer is even more important than the liquidity of the company's securities when the offer is low.

Empirically, Edward and Anderson (2004) do not find a significant negative relationship between the liquidity of shares prior to the offer and the premium. They use the average daily volume of shares traded by the company during a period preceding the announcement of the offer as a liquidity measure.

In the present study, we retained a different measure of the securities' liquidity. which is the average effective spread during the two months preceding the offer (variable: LIQUID). This spread is equal to twice the absolute value of the difference between the share price and the average price between the seller and the buyer price, divided by the average between the buying price and the selling price. A significant spread indicates that the liquidity of securities is low.

For information, the link between repurchases on the market and the liquidity of the company's securities was recently the subject of several studies (Brockman and Chung, 2001; Cook and al, 2004 and Ginglinger and Hamon., 2006) . The latest study was carried out on the French market. It highlights the negative impact of the repurchases on the liquidity of securities. 


\section{The size of the Public Stock Buyback Tender Offer}

According to Anderson and Edward (2004), when the operation involves a high fraction of share capital, a high premium encourages shareholders to accept the offer of the company and then increases the chances of the latter to reach its objectives and to succeed in its Public Stock Buyback Tender Offer. Hence, the following hypothesis:

$\mathbf{H}_{4}$ :The premium of the Public Stock Buyback Tender Offer is even more important than the fraction of capital referred to when the operation is high.

However, empirically, Edward and Anderson (2004) do not find a statistically significant relationship between the premium offered and the size of the Public Stock Buyback Tender Offer.

In this study, the size of the operation SIZE 0 will be measured by the fraction of capital subject to the offer; it is supposed to be positively related to the premium of the offer.

\section{The satisfaction of the oversubscription}

The oversubscription is observed when the number of securities offered is greater than the number of securities that the company is planned to buy as part of a public offering. In this case, two solutions are possible for the company: it may decide to repurchase the over demand (in part or in whole) or it just buy the number of securities originally planned by reducing the demands of the shareholders on a pro rata basis of their detention.

According to Anderson and Edward (2004), overdemand suggests that the company proposed a high premium, which encouraged a significant number of shareholders to sell their securities. D'Mello and Shroff (2000) have studied the conditions of satisfaction of the oversubscription to the Public Stock Buyback Tender Offers. The authors found that the decision to satisfy the oversubscription to the Public Stock Buyback Tender Offers is positively and significantly influenced by the extent of the undervaluation. Companies which accept the repurchase the over demand are those most undervalued. They are therefore encouraged to offer large premiums. Thus, we can formulate the following hypothesis:

$\mathbf{H}_{5}$ : The premium of the Public Stock Buyback Tender Offer is more important for the companies that accept the oversubscription

To empirically test this hypothesis, we retain the variable SUR-SOUS that takes the value "1" if the company decides to repurchase the overdemand is "0" otherwise. This variable is expected to be positively related to the premium of the Public Stock Buyback Tender Offer.

\section{The participation of the majority shareholder in a Public Stock Buyback Tender Offer}

The decision to carry out a Public Stock Buyback Tender Offer is taken by a few "insiders" who control the company, namely the controlling shareholders or the top-level leaders. The participation of these latters in the offer encourages them to set a higher premium in order to profit from this operation. Indeed, this maneuver allows the "insiders" to sell their shares at higher prices than their actual values. This therefore results in a transfer of wealth from shareholders who hold their securities towards those who sell (Fried, 2005). The last hypothesis can be stated as follows:

H6: The premium of the Public Stock Buyback Tender Offers is more important when the majority shareholder participate in the operation 
The variable MAJOR that takes the value "1" if the majority shareholder participates in the Public Stock Buyback Tender Offer is "0", is otherwise retained to test this hypothesis. The expected relationship between this variable and the premium is positive.

Presentation of explanatory variables and descriptive statistics

The definitions of the dependent variable and the explanatory variables mentioned above are presented in Table 4.

Table 4: Definitions and variables measurements

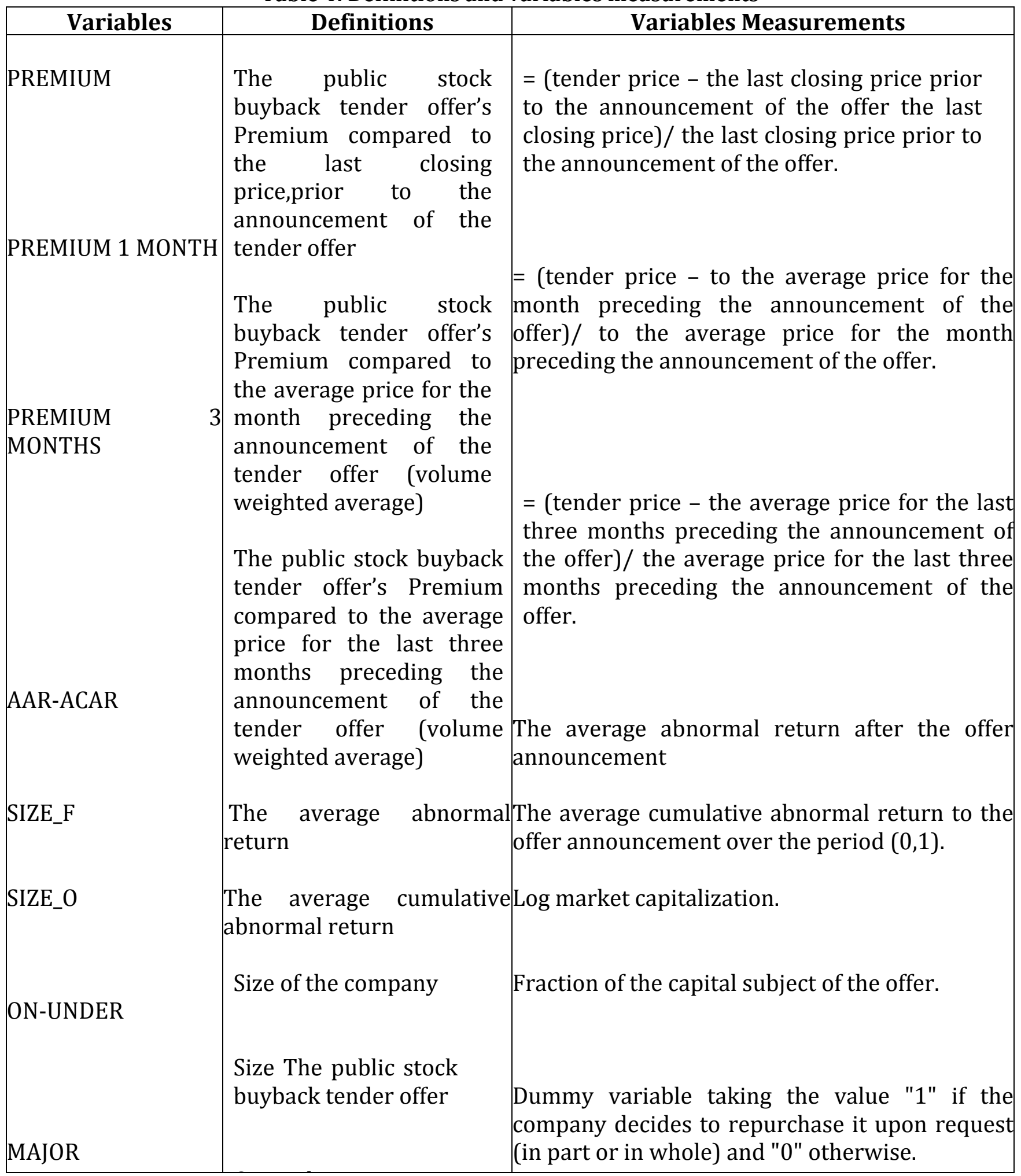


$*$ The effective spread $=\underline{2 *}$ Price of the Security $-($ Bid Price + Ask Price $) / 2 \mid$

(Bid Price + Ask Price)/2

Descriptive statistics are presented in Table 5. For each variable, we calculated the minimum, maximum, average, median and standard deviation.

Table 5: descriptive Statistic

\begin{tabular}{|l|l|l|l|l|l|}
\hline Variables & Minimum & Maximum & Mean & Median & Standard \\
\hline PRIMIUM (\%) & 1,1000 & 72,400 & 23,433 & 20,550 & 16,945 \\
\hline $\begin{array}{l}\text { PRIMIUM 1 MONTH } \\
\text { (\%) }\end{array}$ & 4,2000 & 49,700 & 22,566 & 21,150 & 12,609 \\
\hline $\begin{array}{l}\text { PRIME 3 MONTHS } \\
\text { (\%) }\end{array}$ & 4,300 & 54,200 & 24,622 & 22,250 & 12,110 \\
\hline $\begin{array}{l}\text { Amount PSBTO } \\
\text { (in thousand euros) }\end{array}$ & 2460 & 848378 & 75624 & 26262 & 141616 \\
\hline $\begin{array}{l}\text { NBR PSBTO } \\
\text { (in thousand) }\end{array}$ & 37,600 & 17116 & 2205 & 892 & 3377 \\
\hline \begin{tabular}{l} 
SIZE_F \\
\hline SIZE_0 (\%)
\end{tabular} & 3,473 & 6,493 & 4,977 & 4,975 & 0,671 \\
\hline ACAR\%) & $-2,168$ & 59,591 & 12,856 & 6,751 & 15,112 \\
\hline AAR (\%) & $-7,646$ & 58,540 & 12,137 & 5,455 & 15,568 \\
\hline PERF (\%) & $-23,643$ & 15,852 & 0,295 & 0,901 & 9,329 \\
\hline LIQUID (\%) & 0,103 & 18,600 & 3,578 & 2,160 & 3,928 \\
\hline
\end{tabular}

In the Table 5, the premium compared to the last market price, has an average (median) of $23.4 \%(20.5 \%)$. The average (median) is around $22.5 \%(21.15 \%)$ and $24.6 \%(22.2 \%)$ respectively for the premium during the average price of the month before the offer and the one calculated during the last 3 months preceding the offer.

Given these statistics, we notice that the premiums paid by French companies are comparable to those offered by US companies. In the US market, Dann (1981), Vermaelen (1981) and Masulis (1980) show that the premiums offered during the Public Stock Buyback Tender Offers averaged $22 \%$ to $23 \%$ compared to the last security price before the announcement of the operation. In addition, Anderson and Edward (2004) have recently reported an average premium of $20.55 \%$ compared to the average market price 10 days before the announcement.

Regarding the size of the offer, the amount of the securities repurchased varies between 2.460 billion and 848.378 billion and its average is 75.624 billion. Furthermore, the average (median) of the fraction of the capital referred to, is around 28\% (26\%). These statistics clearly show the importance of the size of the Public Stock Buyback Tender Offer compared to the repurchases on the market that do not allow companies to repurchase more than $10 \%$ of their capital.

As for the variables related to the stock market, the average (median) of the ACAR recorded over the two months preceding the announcement and that of the ACAR calculated one day after the announcement are respectively equal to $0.2 \%(0.9 \%)$ and $12.8 \%(6.7 \%)$. Thus, it 
appears that the performance of securities increases after the announcement of a Public Stock Buyback Tender Offer.

Descriptive statistics also show that companies' securities that carried out Public Stock Buyback Tender Offers, are, on average, very low liquid. Thus, the average (median) of the effective spread, two months before the announcement of the Public Stock Buyback Tender Offer, is equal to $3.578 \%(2.160 \%)$.

Finally, the variable SIZE F, which measures the size of the sample companies with an average of 4,977, a median of 4.975, a standard deviation of 0.671 , a minimum value of 3,473 and a maximum value of 6.493

The correlation matrix of the variables of the study is presented in the table 6

Table 6 : Variables correlation Matrix

\begin{tabular}{|c|c|c|c|c|c|c|c|c|}
\hline & $\begin{array}{l}\text { PRIMIU } \\
\mathrm{M}\end{array}$ & ACAR & $\begin{array}{c}\text { SIZE_ }_{-} \\
\text {F }\end{array}$ & $\begin{array}{c}\text { SIZE_ }_{-} \\
0\end{array}$ & PERF & LIQUID & $\begin{array}{l}\text { ON - } \\
\text { UNDER }\end{array}$ & MAJOR \\
\hline PRIMIUM & 1 & & & & & & & \\
\hline ACAR & $\begin{array}{l}0,653^{* * *} \\
(0,000)\end{array}$ & 1 & & & & & & \\
\hline $\begin{array}{c}\text { SIZE_ }_{-} \\
\mathrm{F}\end{array}$ & $\begin{array}{l}-0,364^{* *} \\
(0,021)\end{array}$ & $\begin{array}{c}-0,262 \\
(0,102)\end{array}$ & 1 & & & & & \\
\hline $\begin{array}{c}\text { SIZE }_{-} \\
0\end{array}$ & $\begin{array}{l}0,386^{* *} \\
(0,014)\end{array}$ & $\begin{array}{l}0,232 \\
(0,149)\end{array}$ & $\begin{array}{l}-0,333^{* *} \\
(0,036)\end{array}$ & 1 & & & & \\
\hline PERF & $\begin{array}{l}-0,418^{* * *} \\
(0,007)\end{array}$ & $0,316^{* *}$ & $\begin{array}{l}0,152 \\
(0,348)\end{array}$ & $\begin{array}{l}-0,339^{* *} \\
(0,033)\end{array}$ & 1 & & & \\
\hline LIQUID & $\begin{array}{l}0,457^{* * *} \\
(0,004)\end{array}$ & $\begin{array}{l}0,041 \\
(0,806)\end{array}$ & $\begin{array}{l}-0,381^{* *} \\
(0,018)\end{array}$ & $\begin{array}{l}0,252 \\
(0,126)\end{array}$ & $\begin{array}{l}-0,244 \\
(0,141)\end{array}$ & 1 & & \\
\hline $\begin{array}{l}\text { ON- } \\
\text { UNDER }\end{array}$ & $\begin{array}{l}0,468^{* * *} \\
(0,003)\end{array}$ & $0,502^{* *}$ & $\begin{array}{l}-0,245 \\
(0,133)\end{array}$ & $\begin{array}{l}0,562^{* * *} \\
(0,000)\end{array}$ & $\begin{array}{l}-0,294^{*} \\
(0,070)\end{array}$ & $\begin{array}{l}0,230 \\
(0,170)\end{array}$ & 1 & \\
\hline MAJOR & $\begin{array}{l}-0,081 \\
(0,629)\end{array}$ & $\overline{0}, 327^{* *}$ & $\begin{array}{l}0,137 \\
(0,413)\end{array}$ & $\begin{array}{l}0,041 \\
(0,809)\end{array}$ & $\begin{array}{l}0,003 \\
(0,985)\end{array}$ & $\begin{array}{l}0,049 \\
(0,778)\end{array}$ & $\begin{array}{l}-0,384^{*} \\
(0,019)\end{array}$ & 1 \\
\hline
\end{tabular}

The correlation table shows a significant and positive link at a threshold of $1 \%$ between the variable PRIME and the variable ACAR. Market reaction to the Public Stock Buyback Tender Offers' announcements depends heavily on the premium offered. This confirms the idea that the premium allows investors to learn about the extent of the undervaluation of the company's securities.

The explained variable PRIME appears, in addition, significantly correlated with all the variables except with the variable MAJOR. Correlation signs are those set out: a negative sign for the size of the company and the performance of its securities before the offer; and a positive sign for the size of the operation, the average effective spread calculated before the offer and the satisfaction of oversubscription.

\section{THE RESULTS OF THE LINEAR REGRESSIONS}

To test the influence of the explanatory variables defined previously on the premium of the offer, we used the method of linear regression.

To avoid multicollinearity problems, we took the precaution of not putting variables correlated to over $20 \%$ (significantly at a threshold of 5\%) in the same regressions. So we were obliged to test 4 "reduced" models to check the links between the premium and our explanatory variables 
Table 7 : Linear Regression results - Explained Variable is the prime offered during the PSBTO

\begin{tabular}{|c|c|c|c|c|c|}
\hline & $\begin{array}{c}\text { Expecte } \\
\mathrm{d} \text { sign }\end{array}$ & Model 1 & Model 2 & Model 3 & Model 4 \\
\hline CONSTANT & & $\begin{array}{l}62,353 \\
(3,410)^{* * *}\end{array}$ & $\begin{array}{l}10,729 \\
(2,047)^{*}\end{array}$ & $\begin{array}{l}14,431 \\
(4,304)^{* * *}\end{array}$ & $\begin{array}{l}17,692 \\
(5,506)^{* * *}\end{array}$ \\
\hline SIZE_F & $(-)$ & $\begin{array}{l}-7,648 \\
(-2,082)^{* *}\end{array}$ & & & \\
\hline SIZE_O PERF & $(+)$ & & $\begin{array}{l}0,294 \\
(2,030)^{* *}\end{array}$ & & \\
\hline LIQUID ON- & $(-)$ & $\begin{array}{l}-0,675 \\
(-2,575)^{* *}\end{array}$ & & $\begin{array}{l}-0,452 \\
(-1,807)^{*}\end{array}$ & $\begin{array}{l}-0,599 \\
(-2,338)^{* *}\end{array}$ \\
\hline UNDER & $(+)$ & & $\begin{array}{l}1,695 \\
(2,644)^{* *}\end{array}$ & $\begin{array}{l}1,431 \\
(2,391)^{* *}\end{array}$ & $\begin{array}{l}1,654 \\
(2,650)^{* *}\end{array}$ \\
\hline MAJOR & $(+)$ & & & $\begin{array}{l}11,186 \\
(2,307)^{* *}\end{array}$ & \\
\hline Adjusted $\mathrm{R}^{2}$ & $(+)$ & $\begin{array}{l}-1,373 \\
(-0,278)\end{array}$ & $\begin{array}{l}-3,768 \\
(-0,782)\end{array}$ & & \\
\hline & & $\begin{array}{l}0,208 \\
(4,407)^{* * *}\end{array}$ & $\begin{array}{l}0,236 \\
(5,013)^{* * *}\end{array}$ & $\begin{array}{l}0,345 \\
(7,851)^{* * *}\end{array}$ & $\begin{array}{l}0,269 \\
(8,162)^{* * *}\end{array}$ \\
\hline
\end{tabular}

The results of these 4 models give an adjusted $\mathrm{R}^{2}$ which varies between $20 \%$ and $34 \%$ and significant values of $\mathrm{F}$ of Fisher at a threshold of $1 \%$ showing that our models are globally important.

In the first equation, the size of the company SIZE F explains negatively and significantly the premium of the offer. In the second equation, the SIZE $O$ variable that measures the size of the operation is positively and significantly related to the PRIME variable. According to these results, the premium offered seems to be more important when the company is small and the fraction of capital referred to during the operation is high.

In the US market, Edward and Anderson (2004) and Comment and Jarrell (1991) show that the premium of the offer is also affected by the size of the company; by cons, it does not depend on the size of the operation.

Regarding the performance of the securities before the offer, the results found in our study confirms those found by Anderson and Edward (2004) and Comment and Jarrell (1991). In the equations 1, 3 and 4, the PERF variable has a negative and significant coefficient. The performance of the securities before the offer, which is measured by the ACAR over the period $(-60,-1)$, negatively influences the premium. When its securities are highly undervalued, the company appears to pay a significant premium in order to reflect the extent of this undervaluation to the investors. This result confirms the hypothesis $\mathrm{H} 2$, which stipulates that the 
premium of the Public Stock Buyback Tender Offer is more important than the performance of the securities when the offer is low.

We also assumed that a low level of liquidity of the security before the tender offer is pushing companies to offer higher premiums. The LIQUID variable defined by the average effective spread during the period $(-60,-1)$ is, in this study, an indicator of the liquidity of the securities. The coefficient of this variable in the equations 2, 3 and 4 is positive and significant. Thus, the liquidity of the security, before the tender offer, has an inverse effect on the premium of the offer, which corroborates the 3rd hypothesis of this study. It should be noted that this impact is not confirmed by Anderson and Edward (2004) who used the average transaction volume calculated over 40 days prior to the tender offer as a measure of liquidity of the company's securities.

Table 7 also shows that the dummy variable ON UNDER, which takes the value "1" if the company decides to repurchase the over demand is "0" otherwise it is significantly and positively related to the variable PRIME. It appears that the companies that accept it on demand, offer significant premiums, which confirms the hypothesis 5

Finally, unlike the explanatory variables evoked, the variable MAJOR does not explain significantly the premium of the tender offer. The link between the premium of the offer and the participation of the majority shareholder in the operation cannot therefore be confirmed.

In other words, smaller companies with less liquid and less efficient securities, accepting the over demand and for a high fraction of capital appear to offer significant premiums.

\section{CONCLUSION}

This article intends to cover The Public Stock Buyback Tender Offers. The motivations of these operations are first of all analyzed. The companies use The Public Stock Buyback Tender Offers in order to report to the market the under-valuation of their securities. They also carry out these operations for some secondary purposes, such as: reducing agency conflicts within the organization, the anti-takeover defense, the expropriation of the creditors and the delisting of their securities

The impact of The Public Stock Buyback Tender Offers conducted in France between 1996 and 2005 on stock prices is then studied. The results of the event studies show that these announcements are welcomed by a very favorable price reaction. This confirms the results found in the US market.

The explanation of the premium determinants of the tender is the subject of the last section. The results of the linear regressions show that the weak liquidity and the performance of securities during the period preceding the Public Stock Buyback Tender Offer appears to encourage companies to pay large premiums.

It also appears from these regressions that smaller companies, which accept the oversubscription and aim for a significant fraction of capital in the tender, are also encouraged to offer high premiums.

As an extension of this work, our future research is concerned, in addition to the features mentioned in this study, with the corporate governance aspects in order to study the reasons for the Public Stock Buyback Tender Offers in a more general context. 


\section{BIBLIOGRAPHIE}

Anderson A.M. et Edward A., 2004, «Determinants of Premiums On self-Tender Offers», Financial Management, Spring 2004, pages 25-45.

Asquith P. et Mullins D.W., 1986, «Equity issues and offering dilution», Journal of Financial Economics, 15, 61-89.

Atiase R.K., 1985, «Predisclosure Information, Firm Capitalization and Security Price Behavior around Earning Announcements», Journal Of Accounting Research, 23, 21-36.

Bagwell L., 1991, «Shareholder heterogeneity: evidence and implications», American Economic Review, 81, 218-221.

Barclay M. and Smith C. Jr, 1988, «Corporate pay out policy: cash dividends versus open market repurchases», Journal of Financial Economics, 22, 61-82.

Barnes T., Burnie D. et Gunay E., 1997, «Note sur les rachats via bourse au Canada (1987-1995)», FINECO, Vol. 7, $n^{\circ} 2,137-146$.

Brockman P. et Chung D. Y., 2001, «Managerial timing and corporate liquidity: evidence from actual share repurchases», Journal of Financial Economics, 3, 417-448.

Choi D. et Chen S., 1997, «The differential information conveyed by share repurchase tender offers and dividend increases», Journal of Financial Research, 20, 529-543.

Comment R. et Jarrell G., 1991, «The Relative Signalling Power of Dutch-Auction and Fixed-Price Self-Tender Offers and Open-Market share Repurchases», Journal of Finance, 46, 1243-1271.

Cook D. O., Krigman L. et Leach J. C., 2003, «An analysis of SEC guidelines for executing open market repurchases», Journal of Business, 2, 289-316.

D’Mello R. et Shroff P., 2000, «Equity Undervaluation and Decisions Related to Repurchase Tender Offers: An Empirical Investigation», The Journal of Finance, 55, 2399-2424.

Dann L.Y, 1981, «Common stock repurchases: an analysis of returns to bondholders and stockholders», Journal of Financial Economic, 9, 131-138.

Dann L.Y., Masulis R.W et Mayers D., 1991, «Repurchase tender offers and earnings information, Journal of Accounting and Economics»14, 217-251.

DeAngelo H., DeAngelo L. et Skinner D. J., 1996, «Reversal of fortune: dividend signalling and the disappearance of sustained earnings growth», Journal of Financial economics, 3, 341-371.

Fried J. M., 2005, «Insider signalling and insider trading with repurchase tender offers», California Law Review, 5, $1326-1386$.

Ginglinger E. et Hamon J., 2006, « Actual share repurchases, timing and corporate liquidity», accepté dans le "Journal of Banking and Finance"

Ginglinger E. et L'Her F., 2006, « Ownership structure and open market stock repurchases in France », The European Journal of Finance, 12, 77-94.

Grubbs FE.,1969, «Procedures for detecting outlying observations in samples», Technometrics, 11, 1-21.

Grullon G. et Ikenberry D., 2000, «What do we know about stock repurchases », Journal of Applied Corporate Finance, 13, 31-51.

Grullon G. et Michaely R., 2004, « The information content of share repurchase programs», Journal of Finance, Vol. 59, 651-680.

Guay W. and Harford J., 2000, «The cash flow permanence and information content of dividend increases vs. repurchases», Journal of Financial economics, Vol. 57, n³, 385-416.

Heflin F., Shaw K.W. et Wild J.J., 2001, «Disclosure Quality and Market Liquidity», Working paper, Purdue University.

Hertzel M.G. et Jain P.C., 1991, «Earnings and risk changes around stock repurchase tender offers», Journal of Accounting and Economics, 14, 253-274.

Hertzel M.G., 1991, «The effects of stock repurchases on rival firms», Journal of Finance, 46, 707-716.

Howe K.M., He J. et Kao G.W., 1992, «One-time cash flow announcements and free cash- flow theory: share repurchases and special dividends», The Journal of Finance, 47, 1 963-1976. 
Ikenberry D., Lakonishok J. et Vermaelen T., 1995, «Market underreaction to open market share repurchases», Journal of Financial Economics, 2, 181-208.

Jensen M, 1986, «Agency costs of free cash flow, corporate finance, and takeovers», American Economic Review, 76, 323-329.

Korajczyk R.A., Lucas D.J. et McDonald R.L., 1990, «Understanding stock price behavior around the time of equity issues», In R. Hubbard (Ed.), Asymmetric Information, Corporate Finance and Investment (University of Chicago Press, Chicago Illinois).

Lakonishok J. et Vermaelen T., 1990, «Anomalous Price Behavior around Repurchase Tender Offers», Journal of Finance, 45, 455-477.

Lie E. et McConnell J. J., 1998, «Earnings signals in fixed-price and dutch auction self- tender offers», Journal of Financial Economics, 49, 161-186.

Lie E., 2000, «Excess funds and agency problems: an empirical study of increment cash disbursments», Review of Financial studies, 13, 219-248.

Masulis R., 1980, «Stock Repurchase by tender offer: an analysis of the cause of common stock price changes», Journal of Finance, 35, 2, 305-321.

Masulis R.W. et Korwar A.N., 1986, «Seasoned equity offerings: An empirical investigation», Journal of Financial Economics, 15, 91-118.

Maxwell W. et Stephens C., 2003, «The wealth effects of repurchases on bondholders », Journal of Finance, 2, 895920.

Merton R.C., 1987, «A simple Model Of capital Equilibrium with Incomplete Information », Journal of Financial Economics, 14, 165-194.

Nohel T. and Tarhan V., 1998, «Share repurchases and firm performance: new evidence on the agency costs of free cash flows», Journal of Financial Economics, 49, 187-222.

Perfect S., Petersen D. et Petersen P., 1995, «Self tender offers : the effects of free cash flow, cash flow signalling, and the measurement of Tobin's Q», Journal of Banking and Finance, 6, 1 005-1 023.

Planchon V., 2005, «Traitement des valeurs aberrantes : concepts actuels et tendances générales», Biotechnol. Agron. Soc. Environ, 9, 19-34.

Shleifer A., Vishny R.W. et Morck R., 1988, «Alternative mechanisms for corporate control», American Economic Review, 4, 842-852.

Stephens C. P. et Weisbach M. S., 1998, «Actual share reacquisitions in open-market repurchase programs», Journal of Finance, 53, 313-333.

Stulz R., 1988, «Managerial control of voting rights: financing policies and the market for corporate control», Journal of Financial Economics, 20, 25-54.

Vermaelen T., 1981, «Common Stock Repurchases and Market Signalling: An Empirical Study», Journal of Financial Economics, 9, 139-183

Vermaelen T., 1984, «Repurchase Tender Offers, Signaling and Managerial Incentives», Journal of financial and Quantitative Analysis, 19, 163-181. 